\title{
Fire regimes and vegetation responses in two Mediterranean-climate regions
}

\author{
Regímenes de incendios y respuestas de la vegetación en dos regiones de clima Mediterráneo
}

\author{
GLORIA MONTENEGRO ${ }^{1}$, ROSANNA GINOCCHIO ${ }^{2}$, ALEJANDRO SEGURA ${ }^{3}$, \\ JOHN E. KEELY ${ }^{4} \&$ MIGUEL GÓMEZ ${ }^{1}$
}

\author{
${ }^{1}$ Departamento de Ciencias Vegetales, Facultad de Agronomía e Ingeniería Forestal, \\ Pontificia Universidad Católica de Chile, Avenida Vicuña Mackenna 4860, Macul, Santiago, Chile; e-mail: gmonten@puc.cl \\ ${ }^{2}$ Centro de Investigación Minera y Metalúrgica, Avenida Parque Antonio Rabat 6500, Vitacura, Santiago, Chile \\ ${ }^{3}$ Gestión Ambiental, Padre Mariano 103 oficina 307, Providencia, Santiago, Chile \\ ${ }^{4}$ United States Geological Survey, Western Ecological Research Center, Sequoia-Kings Canyon Field Station, Three \\ Rivers, California 93271-9651, USA
}

\begin{abstract}
Wildfires resulting from thunderstorms are common in some Mediterranean-climate regions, such as southern California, and have played an important role in the ecology and evolution of the flora. Mediterranean-climate regions are major centers for human population and thus anthropogenic impacts on fire regimes may have important consequences on these plant formations. However, changes in fire regimes may have different impacts on Mediterranean type-ecosystems depending on the capability of plants to respond to such perturbations. Therefore, we compare here fire regimes and vegetation responses of two Mediterraneanclimate regions which differ in wildfire regimes and history of human occupation, the central zone of Chile (matorral) and the southern area of California in United States (chaparral). In Chile almost all fires result from anthropogenic activities, whereas lightning fires resulting from thunderstorms are frequent in California. In both regions fires are more frequent in summer, due to high accumulation of dry plant biomass for ignition. Humans have markedly increased fires frequency both in the matorral and chaparral, but extent of burned areas has remained unaltered, probably due to better fire suppression actions and a decline in the built-up of dry plant fuel associated to increased landscape fragmentation with less flammable agricultural and urban developments. As expected, post-fire plant regeneration responses differs between the matorral and chaparral due to differences in the importance of wildfires as a natural evolutionary force in the system. Plants from the chaparral show a broader range of post-fire regeneration responses than the matorral, from basal resprouting, to lignotuber resprouting, and to fire-stimulated germination and flowering with fire-specific clues such as heat shock, chemicals from smoke or charred wood. Plants from the matorral have some resprouting capabilities after fire, but these probably evolved from other environmental pressures, such as severe and long summer droughts, herbivory, and volcanism. Although both Mediterranean-type ecosystems have shown to be resilient to anthropogenic fires, increasing fire frequency may be an important factor that needs to be considered as it may result in strong negative effects on plant successional trends and on plant diversity.
\end{abstract}

Key words: human impacts, plant regeneration, matorral, chaparral.

\section{RESUMEN}

Los incendios forestales originados por tormentas estivales son una característica común en la mayoría de las regiones con clima Mediterráneo, tal como el sur de California, y han jugado un rol importante en la ecología y evolución de su flora. Las regiones con clima Mediterráneo han sido, además, centros importantes para el establecimiento de poblaciones humanas, las que al alterar los regímenes de incendios podrían producir efectos negativos importantes en este tipo de formaciones vegetales. Sin embargo, los efectos antrópicos sobre el régimen de incendios podrían tener impactos distintos en ecosistemas Mediterráneos cuya vegetación ha evolucionado naturalmente con este tipo de perturbación. Así, en este trabajo comparamos los regímenes de incendios y la capacidad de respuesta de la vegetación de dos regiones con clima Mediterráneo que han tenido historias distintas en cuanto a la ocurrencia natural de incendios forestales y de ocupación humana, tales como la zona central de Chile (matorral) y el sur de California (chaparral). En Chile, casi todos los incendios forestales son el resultado de actividades antrópicas, mientras que en California los incendios producidos por el hombre se suman a los producidos por tormentas estivales. En ambas regiones, los incendios son más frecuentes en verano debido a la acumulación de biomasa vegetal seca altamente combustible. El hombre ha incrementado significativamente la frecuencia de incendios tanto en el matorral como en el chaparral en las últimas décadas, pero la extensión de los incendios no se ha incrementado en forma importante, probablemente debido a mejores sistemas de supresión del fuego y a la menor acumulación de biomasa vegetal seca por el aumento de la 
fragmentación del paisaje con desarrollos urbanos y agrícolas con menor potencial de combustión. Como se esperaba, las respuestas de regeneración de las plantas después de los incendios son distintas en el matorral y en el chaparral. Las plantas del matorral muestran un rango de respuestas regenerativas mayor, las que van desde el rebrote basal, al rebrote desde el lignotuber y a la germinación y floración estimuladas por el fuego, con estímulos fuego-específicos tales como shock térmico, químicos presentes en el humo y en la madera quemada. Las plantas del matorral tienen cierta capacidad de regeneración después del fuego, pero estas probablemente evolucionaron como consecuencia de otras presiones ambientales, tales como las severas y largas sequías de verano, la herbivoría y el volcanismo. Aunque ambos ecosistemas de tipo Mediterráneo han mostrado ser resistentes a los incendios de origen antrópico, el marcado aumento en la frecuencia de estos puede constituir un aspecto muy importante de considerar, ya que puede resultar en efectos negativos importantes tanto en los patrones sucesionales como en la diversidad vegetal.

Palabras clave: impactos antrópicos, regeneración vegetal, matorral, chaparral.

\section{INTRODUCTION}

Mediterranean-climate regions occupy less than $5 \%$ of the Earth's surface, yet they contain about $20 \%$ of the world's flora (Cowling et al. 1996). These regions are also major centers of human population growth and thus anthropogenic impacts on natural ecosystems have been a matter of concern, particularly because of the potential for introducing new disturbances or altering the frequency and intensity of the existing ones (Mooney et al.1986, Fuentes et al. 1990, 1995).

Wildfires are a common feature of some Mediterranean-climate regions and they have long played an important role in the ecology and evolution of the flora. The autumn, winter, and spring rains, coupled with mild temperatures, support the growth of a diversity of shrubs, herbs and grasses thus resulting in a continuous stand of vegetation. The long summer drought produce extensive areas of dry biomass with highly flammable conditions and once ignited, the stand structure contributes to rapid fire spread. However, human settlement and associate activities have impacted natural fire regimes in these landscapes (Keeley et al. 1989, Minnich 1989). For instance, continuous and successful fire prevention practices in some Mediterranean-climate regions have resulted in important effects on ecosystem function, but on the other hand, prolonged buildup of fuel have resulted on highly destructive fires (Keeley \& Keeley 1986).

We contrast here the role of natural (lightning-ignited) wildfires and the impact of anthropogenic fires on vegetation of two contrasting Mediterranean-climate regions, the Chilean matorral and the Californian chaparral, because of their differences in natural fire regimes and land use histories (Mooney 1977). Europeans colonized central Chile several centuries earlier than California. While relatively little exploitation of natural resources occurred prior to the industrial revolution in California, strong impacts on natural ecosystems associated to subsistence lifestyles of rural populations have played an important role on the structure and function of the Chilean matorral (Bahre 1979, Aschmann 1991).

\section{Fire regimes in Chile and California}

Influence of the Mediterranean climate on timing of wildfires is clear from their seasonal distribution in Chile and California (Fig. 1 and 2 ). Fires are more frequent on summer months in both regions, but a significant fire hazard is also present throughout the year in California. One possible explanation for this may lie on sociological patterns associated to holiday travels; massive population movements from main cities to rural areas and coastal towns are concentrated in summer months in Chile (summer holiday), while travels associated to holidays are often spread out over the year in California. A complementary explanation may also lie in the causes of wildfires.

In Chile, wildfires are almost all result of anthropogenic activities and "natural" lightningignited fires are very rare in the official records (Table 1). Lightning fires, with ignitions resulting from thunderstorms, are clearly not described for Chile as they are for other areas with similar climates around the world, such as California, the southwestern Cape of Africa, southwestern Australia and the Mediterranean Basin (Aschmann \& Bahre 1977, Araya \& Avila 1981, Rundel 1981, Avila et al. 1988, Montenegro et al. 2002). Although, it has been hypothesized that other natural sources of fire may have been rare in Chile, (Mooney 1977, Armesto \& Gutiérrez 1978), Fuentes \& Espinoza (1986) have argued that volcanism, an unusually frequent phenomenon in Chile, may have served as a non-human ignition source, based on published botanical paleontological and geological evidence. However, California 


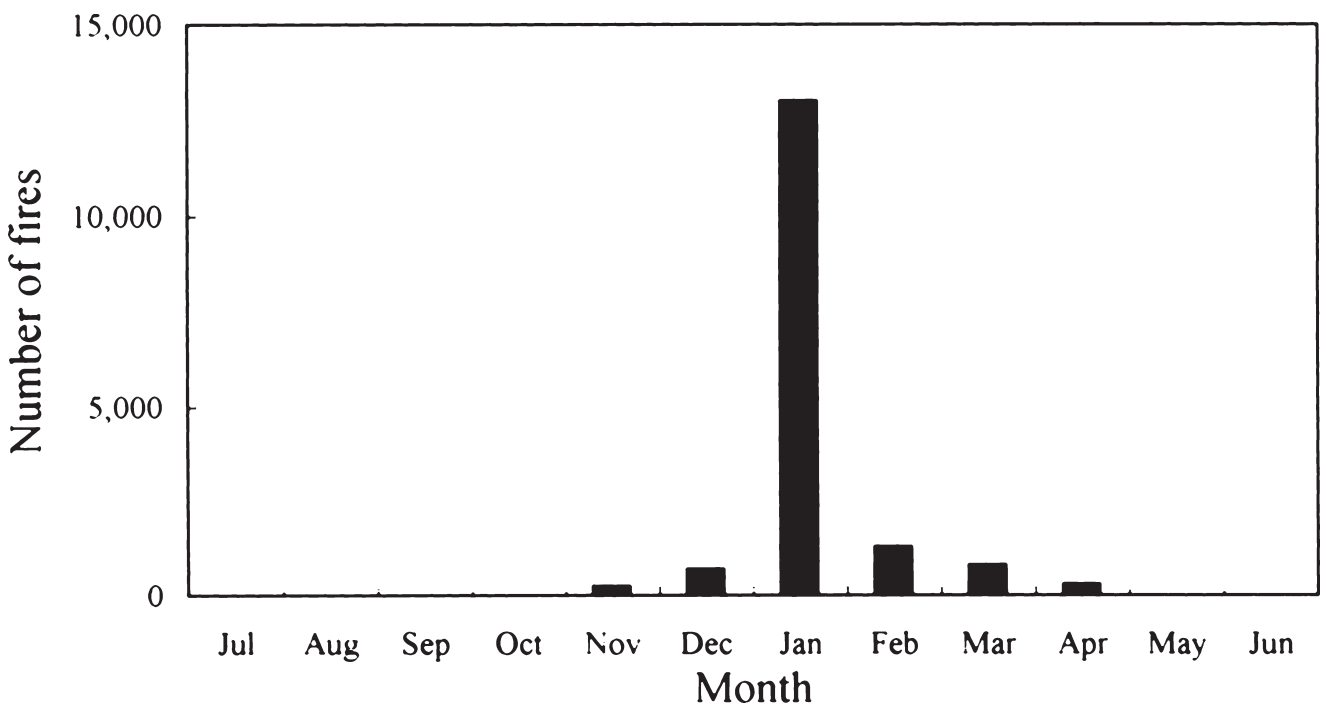

Fig. 1: Seasonal distribution of fires in Chile between 1978 and1995 (data from CONAF 1995). Distribución estacional de los incendios en Chile entre 1978 y 1995 (datos de CONAF 1995).

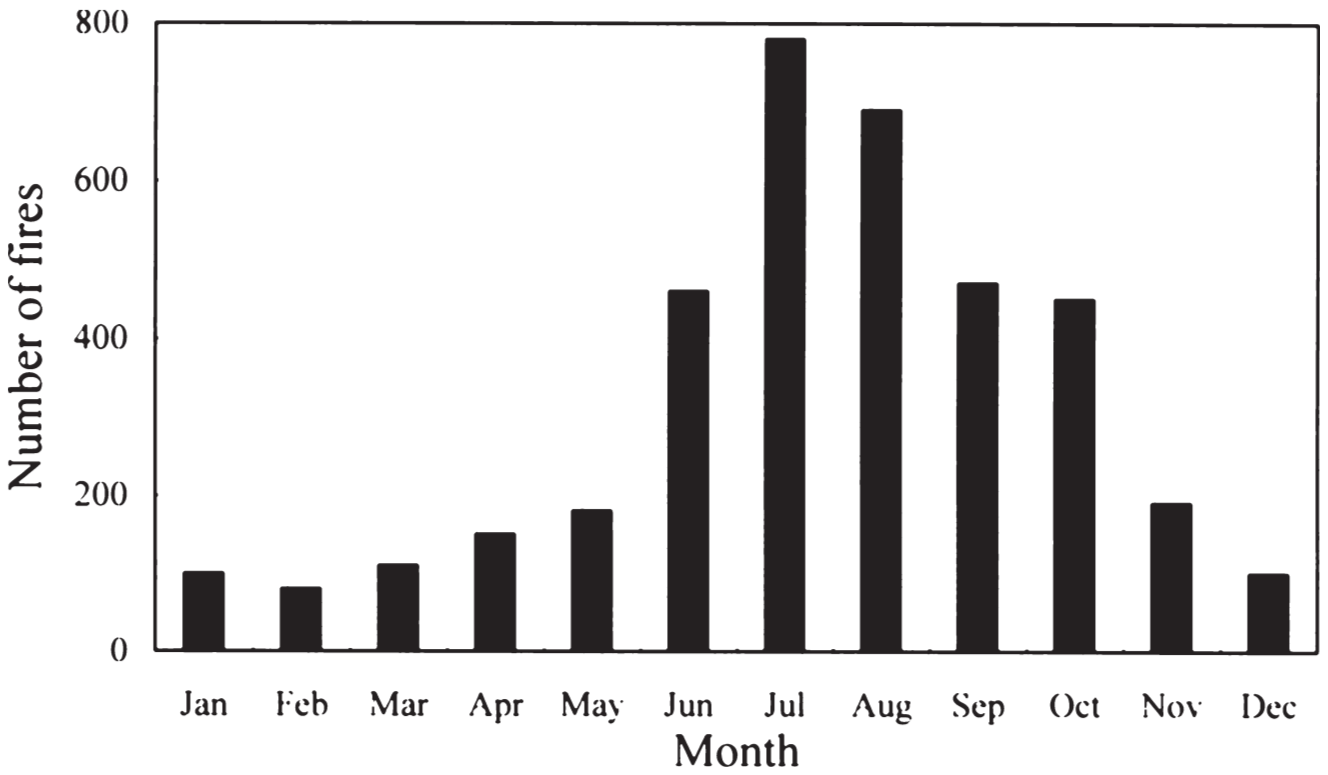

Fig. 2: Seasonal distribution of fires in southern and central California for the period 1910-1997 (data from Keeley et al. 1999).

Distribución estacional de los incendios en California central y sur para el período 1910-1997 (datos de Keeley et al. 1999).

markedly contrasts with Chile where lightning is a frequent and significant source of ignitions (Table 2). Nonetheless, humans account for a substantial number of ignitions in California as well as in Chile.

Further suggestion for the importance of humans on fire regimes in these regions is the significant increase of wildfires in recent decades, both in Chile (Fig. 3) and in California (Fig. 4). Although the Chilean data shown here is for the whole country, the trend is very similar when restricted to the central region with temperate Mediterranean climatetype (Zunino \& Riveros 1990). The increase in 


\section{TABLE 1}

Causes of wildfires in Chile for the period 1986-1990 $(n=3955)$. Data from CONAF Causas de los incendios forestales en Chile para el período 1986-1990 ( $\mathrm{n}=3955)$. Datos de CONAF

\begin{tabular}{lc}
\hline Cause & Percentage $(\%)$ \\
\hline Transportation & 30 \\
Forestry/agriculture & 20 \\
Recreation & 19 \\
Military & 12 \\
Incendiary & 14 \\
Unknown & 5 \\
\hline
\end{tabular}

TABLE 2

Frequency and extent of burning by natural lightning fires and anthropogenic causes on State and federal wildlands in California (1970-1979) (from Keeley 1982)

Frecuencia y extensión de los incendios forestales producidos por causas naturales y antropogénicas en áreas silvestres de California (1970-1979) (Keeley 1982)

\begin{tabular}{lcccc}
\hline Jurisdiction & \multicolumn{2}{c}{ Fires $\left(10^{6} \text { ha yr }\right)^{-1}$} & & Hectares burned $\left(10^{6} \text { ha year }\right)^{-1}$ \\
\cline { 2 - 3 } & Humans & Lightning & Humans & Lightning \\
\hline State of California, & 541 & 31 & 3347 & 416 \\
Division of Forestry & 134 & 129 & 669 & 189 \\
United States Forest Service & 134 & & & \\
\hline
\end{tabular}

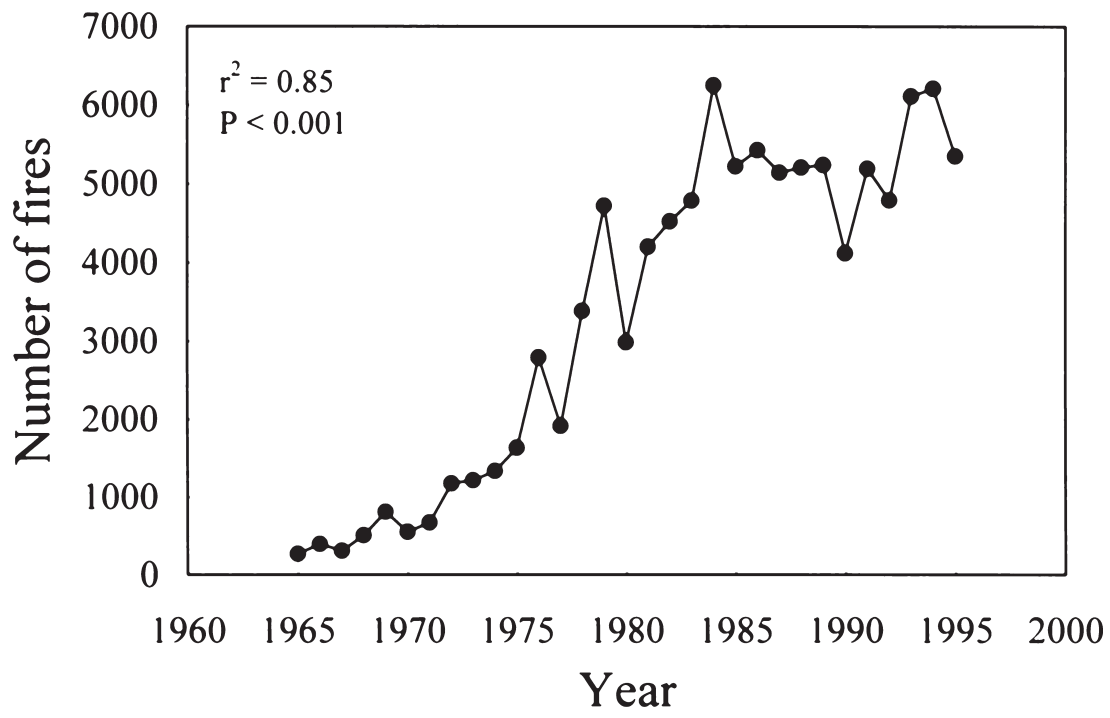

Fig. 3: Annual fire frequency in Chile for the period 1965-1994 (data from CONAF 1995). Frecuencia anual de incendios en Chile para el período 1965-1994 (datos de CONAF 1995). 


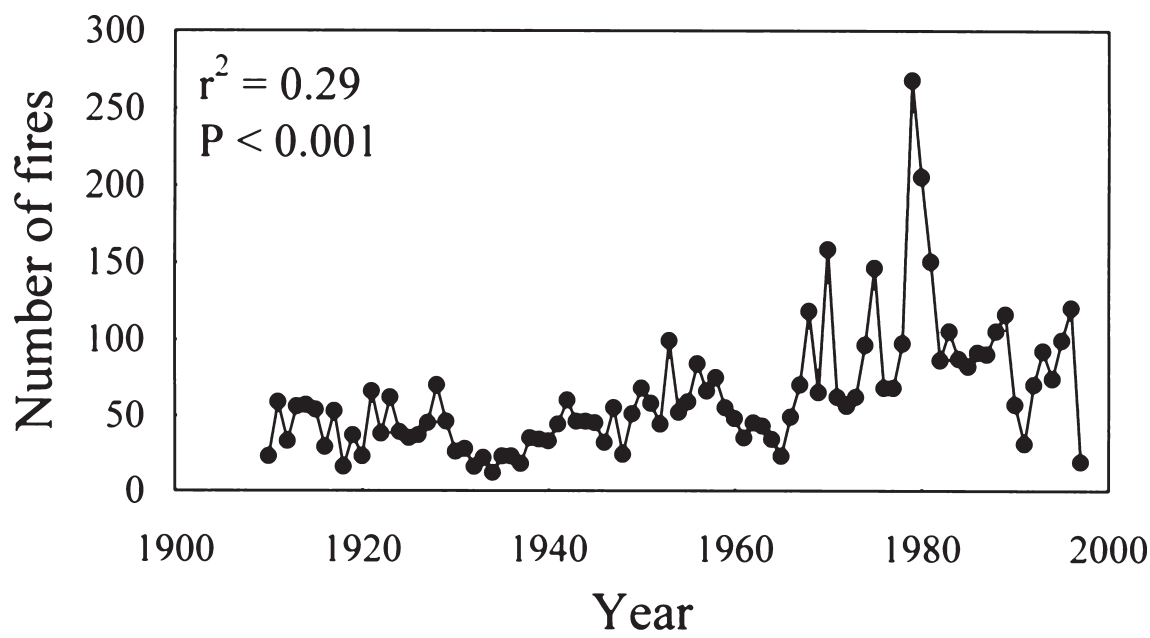

Fig. 4: Annual fire frequency of southern and central California for the period 1910-1997 (data from Keeley et al. 1999).

Frecuencia anual de incendios en el centro y sur de California en el período 1910-1997 (datos tomados de Keeley et al. 1999).

fire frequency closely follows the accelerate population growth produced in both Mediterranean regions over the same period (Palmer 1993).

Although fire frequency has increased in both regions, there is no evidence that the total area burned has increased over the same period in Chile (Fig. 5) and in California (Fig. 6). Reasons for the lack of correlation between fire frequency and surface of burned area are many and complex, but the obvious one may be that average fire size has declined with time due to effective fire suppression (Keeley \& Keeley 1986). Furthermore, the increased fragmentation of wild habitats that has accompanied accelerated population growth and development (Lepart \& Debussche 1992) also reduce surface of wild areas that can be potentially burned. In Chile and California, Mediterranean landscapes have been altered by replacing vast stretches of contiguous wild ligneous vegetation for patches of vegetation dispersed in a mosaic interspersed with less flammable agricultural, weedy herbaceous

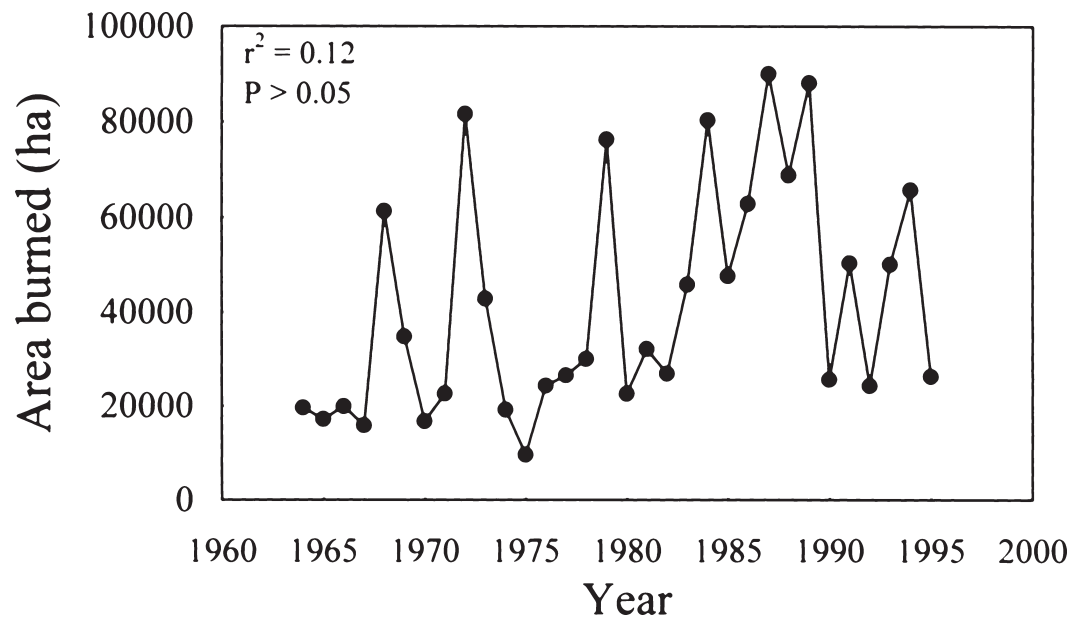

Fig. 5: Annual area burned in Chile for the period 1965-1994 (data from CONAF 1995).

Área anual quemada en Chile en el período 1965-1994 (datos de CONAF 1995). 


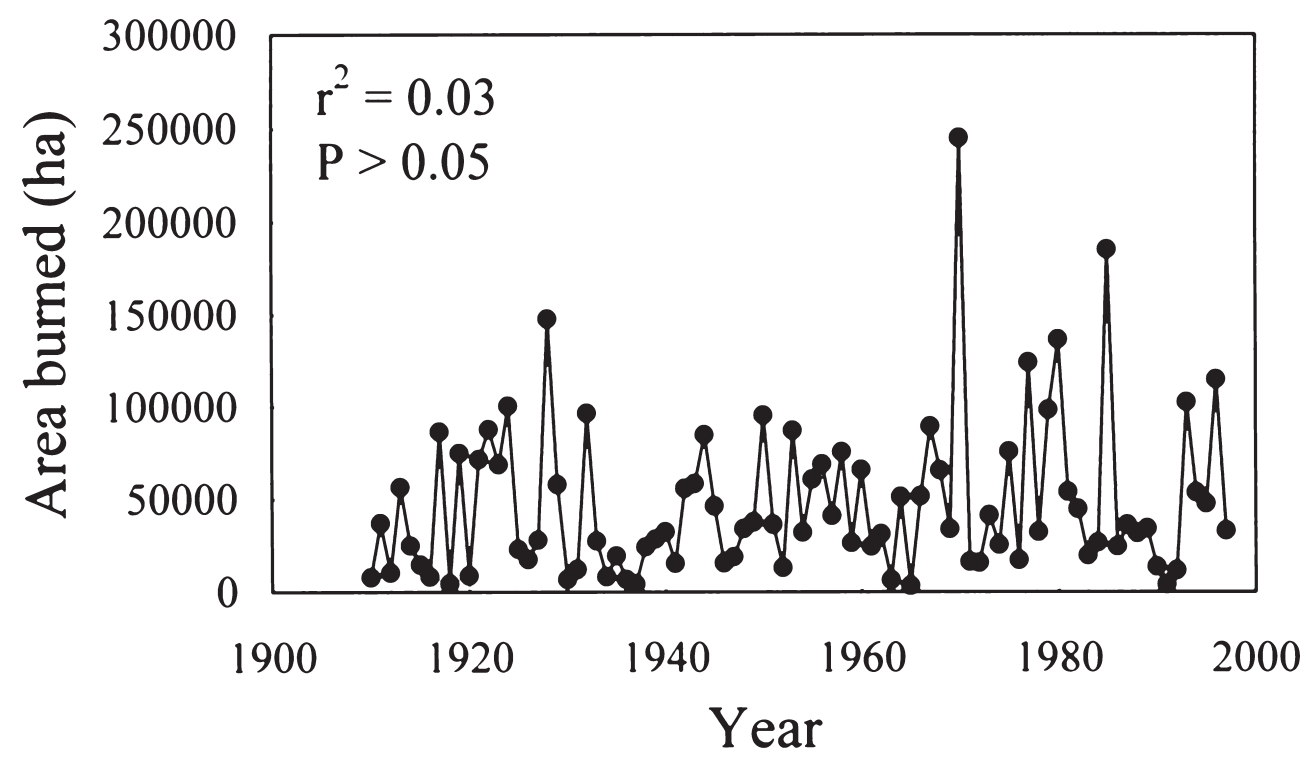

Fig. 6: Annual area burned in southern and central California for the period 1910-1997 (data from Keeley et al. 1999).

Área anual quemada en el centro y sur de California en el período 1910-1997 (datos tomados de Keeley et al. 1999).

communities and suburban vegetation, as well as non-flammable urban developments. Therefore, if the total area burned has remained the same then it is likely that the effective fire suppression, particularly near urban centers, and the heterogeneity in burning of the mosaics generated from the landscape fragmentation has lead to differences in the fire return interval. For instance, in areas near urban centers a low return interval of fire may be expected due to less flammability of developments and effective fire suppression while a high return interval may be expected in other areas.

The net effect would appear to largely offset increased fire incidence and thus it would appear that despite increased fire incidence there has been no net impact on fire regime. However, this notion needs to be tempered by recognition that while burned area may, broadly speaking, be roughly the same over time, the surface extent of natural vegetation has declined. As a consequence, for any given parcel of natural vegetation, fire frequency has likely increased in recent decades. As a consequence, dry plant fuel built-up has likely declined, further reducing flammability of stands, thus contributing to a reduction in fire spread and ultimate fire size.
Vegetation response to fires in Chile and California

The marked similarity in vegetation structure and function between the Mediterraneanclimate regions of Chile and California has been well described (Mooney \& Parsons 1973, Parsons \& Moldenke1975, Parsons 1976, Mooney 1977). This apply at the landscape level, where resemblance exist between sclerophyllous shrublands and woodlands of central Chile and California (Mooney et al. 1970), besides similar vegetation patterns of polar-versus equator-facing aspects (Armesto \& Martínez 1978). However, differences in the importance of wildfires as an evolutionary force for plant formations may have resulted in different post-fire regeneration strategies in the chaparral and the matorral.

Post-fire plant regeneration responses are summarized in Table 3. Comparison between both Mediterranean regions has been focused on chaparral and matorral plant formations and not on the whole schlerophyllous Mediterranean-type vegetation. Fire regimes in both regions essentially preclude epicormic sprouting. Stand structure and fuel loads may generate catastrophic stand-replacing fires, 
TABLE 3

Post-fire regeneration responses and their relative importance in Californian chaparral and Chilean matorral $(++++$, frequent response shown by plants; ++ , less frequent response; +/- uncommon response; -, not found response)

Respuestas de regeneración post-fuego y su importancia relativa en el chaparral californiano y el matorral chileno (++++, respuesta frecuente; ++, respuesta menos frecuente; +/- respuesta poco común; -, respuesta no detectada)

\begin{tabular}{lcc}
\hline Response & Chaparral & Matorral \\
\hline Resprouting from epicormic stem buds & - & - \\
Resprouting from roots or the root crown & ++++ & ++++ \\
Resprouting from lignotuber & ++++ & ++ \\
Resprouting from deeply buried bulbs or corms & ++ & ++ ? \\
Fire-stimulated flowering & ++ & - \\
Release of seeds from serotinous cones or fruits & ++++ & + \\
Germination of dormant soil-seed banks stimulated by heat shock & ++++ & $-?$ \\
Germination of dormant soil-seed banks stimulated by chemicals from smoke or charred wood & ++ \\
\hline
\end{tabular}

leaving scarce aboveground living tissues. This contrast with woodland communities, where thick bark and self-pruning of hardwood trees, such as Quercus agrifolia in California and Cryptocarya alba in Chile, make epicormic sprouting a viable option.

Basal resprouting is common in the woody flora of both regions. Indeed, this is the primary mechanism responsible for persistence of many species in the face of frequent fires. In other words, in both regions a large proportion of the dominant woody flora fail to recruit seedlings immediately after fire and would be locally extinct from the site if not for vegetative regeneration. While resprouting is clearly adaptive in this context, it is a matter of some debate whether or not resprouting was initially selected for as a response to fire. Deposition of adventitious buds in the root crowns of woody plants is a nearly ubiquitous trait in dicotyledonous plants (Wells 1969). Although wildfires are an important feature of many ecosystems worldwide and have been present since the early evolution of angiosperms, there are other disturbance factors that could select for this trait, such as extended drought and herbivory.

Chilean matorral differs significantly from Californian chaparral in that all woody species can resprout after fire (Parsons 1976, Mooney 1977, Araya \& Ávila 1981, Montenegro et al. 1983), while a substantial proportion of the Californian chaparral shrub species fail to resprout, even after low intensity fires (Wells 1969). These non-sprouters or obligate seeders recruit massive seedling populations after fire and are considered highly specialized "firedependent" species (Keeley 1986).

Another common fire adaptation is the presence of swollen "basal burls" or lignotubers, which are structures, composed of many adventitious buds from which resprouts may arise. Such structures are produced by a number of widely distributed shrub species in both the Californian chaparral and the Chilean matorral. Storage of carbohydrates is an important role for such structures, and there is strong experimental evidence showing that seasonal depletion of carbohydrates may strongly affect regenerative power from lignotubers (Rundel et al. 1987). For example, it has been shown that the starch stored in lignotubers of Cryptocarya alba, a tree from the central zone of Chile, is used as an effective energy source for the built-up of a new canopy after the fire (Gómez 2003). The starch content in lignotubers of burned trees decreases $70 \%$ during the first month of regeneration after fire and it does not recover until the next plantgrowth season. However, only a small percentage of woody plants found in the Mediterranean climate-type ecosystems has lignotubers. These structures are ontogenetic features that are programmed to be developed in the early seedling growth (Wells 1969, Montenegro et al. 1983). This contrast with lignotuber development detected in most nonMediterranean-climate species, where the basal swelling is a wound response to strong damage in aboveground stems (Keeley 1981).

Geophytes are a diverse and abundant component of all Mediterranean climate-type 
regions (Dafni et al. 1981, Rundel 1996). In some respects their life cycle pre-adapts them to fires, since their seasonal cycle involves a dormancy period where aboveground tissues die back. The dormancy period of these plants coincides with the fire season of Mediterranean climate-type regions, and thus geophytes are well buffered against fires, as it seems likely that the deeply buried corms and bulbs are not negatively affected by fire. Furthermore, such species positively respond to fire by virtue of having much greater frequency of flowering (Stone 1951, Rundel 1981, Le Maitre \& Brown 1992), stimulated perhaps by enhanced nutrients and light availability after fire. One very extreme example of fire-following flowering is the geophyte Cyrtanthus ventricosum, which flowers immediately (and only) after fire, being triggered by smoke (Keeley 1993). Chile and California are remarkably similar in the proportion of their flora comprised of geophytes, $5.4 \%$ in both regions (Rundel 1996).

Species that accumulate seed banks between fires and produce a pulse of seedling recruitment in the first growing season after fire are common in Mediterranean-climate regions (Keeley 1994). However, Chile greatly differs from the other four regions in this respect, including California. Canopy storage of quiescent seeds in serotinous cones or fruits, which is well developed in South Africa and Australia, and present in California and the Mediterranean Basin, is unknown in Chile. Deeply dormant seeds stored in the soil are common and widespread in the other four regions, but only weakly developed in Chile. One species Retanilla trinervia (Trevoa trinervis), does commonly establish seedlings immediately after fire (Keeley \& Johnson 1977), although the degree to which recruitment is disturbance or fire dependent is not known. "Fire-endemic" annuals common in chaparral are rare in the Chilean matorral (Keeley \& Johnson 1977, Ávila et al. 1981). While firestimulated germination is common and widespread in the Californian chaparral, it is relatively rare in the Chilean matorral (Muñoz \& Fuentes 1989, Keeley 1994). Based on seed coat characteristics and affinities, the Chilean shrub Retanilla trinervia (Rhamnaceae) is most likely stimulated to germinate by heat shock, as it is the case with all fire-stimulated chaparral species of Ceanothus and South African fynbos species of Phylic, both of which are Rhamnaceae (JE Keeley personal communication).

Germination triggered by chemicals from charred wood or smoke is widespread in Californian chaparral, South African fynbos and Australian kwongan, heath and other associations (de Lange \& Boucher 1990, Brown 1993, Keeley 1994, Dixon et al. 1995, Keeley \& Fotheringham 1997). It is clearly the most specialized cue tying germination to post-fire conditions. To date, this mechanism has not been reported for the Chilean flora. Based on the relatively scarce flora that recruit from seed banks after fire, it seems unlikely that this response is widespread in the Chilean matorral (Montenegro et al. 2002).

\section{Vegetation resilience and dependence on fire in Chile and California}

Models of community-level response to disturbance vary from situations where vegetation is totally replaced by temporary successional species, which colonize from outside the system, to communities where immediate post-disturbance regeneration is from the original in situ vegetation. Hanes (1971) termed this latter model "auto-successional," to describe post-fire Californian chaparral where the pre-fire flora is fully represented in the immediate post-fire flora. Nonetheless, fire does generate major structural and floristic changes in the chaparral community. In particular, the dominant shrubland communities are typically replaced by a short-lived herbaceous or subligneous vegetation. The woody flora itself structurally changes, in that shrubs are replaced by either seedlings or herbaceous resprouts from basal lignotubers or roots. Evidence suggests that fires have been a natural part of the Californian Mediterranean climate-type ecosystems prior to anthropogenic influences, but the Chilean matorral appears to have had little evolutionary exposure to fires. As a consequence, we see that a substantial portion of the Californian flora is fire-dependent, and because of specific chemical germination cues requires the disturbance of fire to complete a life cycle. Such is not the case in the Chilean matorral, as all species appear to have some significant capacity for regeneration in the absence of fire, and thus represent a very different successional model than chaparral (Armesto \& Pickett 1985).

The present anthropogenic impact on these regions appears to be one of increasing fire frequency (Fig. 1 and 2). The impact of fires on vegetation structure is, of course, a function of the perturbation frequency and intensity. Therefore, the impact of more frequent fires on the Californian chaparral is a function of whether or not repeated fires occur frequently enough to prevent the non-sprouting shrub 
element from establishing a seed bank sufficient to regenerate the population. In Chile, this is apparently not a problem, though as with chaparral, high fire frequency may reduce survivorship of resprouting species and over time this may reduce plant population sizes. In Chile, there is also the confounding effect of additional pressures on the vegetation in the form of intensive browsing by domestic goats and wood gathering for charcoal production, two not important perturbations in the Californian chaparral. A consequence of these anthropogenic impacts in both Mediterranean regions is that areas in close proximity to urban developments often exhibit marked declines in the woody component of the flora and an increase in non-native annual grasses and forbs. Proyecto Fia CO1-1-G-002.

\section{LITERATURE CITED}

ARAYA S \& G ÁVILA (1981) Rebrote de arbustos afectados por fuego en el matorral chileno. Anales del $\mathrm{Mu}$ seo de Historia Natural de Valparaíso 14: 107-113.

ARMESTO JJ \& JR GUTIÉRREZ (1978) El efecto del fuego en la estructura de la vegetación de Chile central. Anales del Museo de Historia Natural de Valparaíso 11: 43-48.

ARMESTO JJ \& JA MARTÍNEZ (1978) Relations between vegetation structure and slope aspect in the Mediterranean region of Chile. Journal of Ecology 66: 881-889.

ARMESTO JJ \& STA PICKETT (1985) A mechanistic approach to the study of succession in the Chilean matorral. Revista Chilena de Historia Natural 58: 9-17.

ASCHMANN H (1991) Human impact on the biota of Mediterranean-climate regions of Chile and California. In: Groves RH \& F di Castri (eds) Biogeography of Mediterranean invasions: 33-42. Cambridge University Press, New York, New York, USA.

ASCHMANN H \& C BAHRE (1977) Man's impact on the wild landscape. In: Mooney HA (ed) Convergent evolution of Chile and California Mediterranean climate ecosystems: 73-84. Dowden, Hutchinson \& Ross, Stroudsburg, Pennsylvania, USA.

ÁVILA G, ME ALJARO \& B SILVA (1981) Observaciones en el estrato herbáceo después del fuego. Anales del Museo de Historia Natural de Valparaíso 14: 99-105.

ÁVILA G, G MONTENEGRO \& ME ALJARO (1988) Incendios en la vegetación mediterránea. In: Fuentes E \& S Prenafeta (eds) Ecología del paisaje en Chile central. Estudios sobre sus espacios montañosos: 81-88. Ediciones Universidad Católica de Chile, Santiago, Chile.

BAHRE CJ (1979) Destruction of the natural vegetation of north-central Chile. University of California Publications in Geography 23: 1-117.

BROWN NAC (1993) Promotion of germination of fynbos seeds by plant-derived smoke. New Phytologist 123: 575-584

COWLING RM, PW RUNDEL, BB LAMONT, MK ARROYO \& M ARIANOUTSOU (1996) Plant diversity in Mediterranean-climate regions. Trends in Ecology and Evolution 11: 362-366.
DAFNI A, D COHEN \& I NOY-MEIR (1981) Life-cycle variation in geophytes. Annals of the Missouri Botanical Garden 68: 652-660.

DE LANGE JH \& C BOUCHER (1990) Autecological studies on Audouinia capitata (Bruniaceae). I. Plant-derived smoke as a seed germination cue. South African Journal of Botany 56: 700-703.

DIXON KW, S ROCHE \& JS PATE (1995) The promotive effect of smoke derived from burnt native vegetation on seed germination of western Australian plants. Oecologia 101: 185-192.

FUENTES ER, R AVILÉS, \& A SEGURA (1990) The natural vegetation of a heavily-man transformed landscape: the savanna of central Chile. Interciencia 15: 293-295.

FUENTES ER \& G ESPINOZA (1986) Resilience of shrublands in central Chile: a volcanism-related hypothesis. Interciencia 11: 164-165.

FUENTES ER, G MONTENEGRO, P RUNDEL, MTK ARROYO, R GINOCCHIO \& F JAKSIC (1995) Functional approaches to biodiversity in the Mediterranean-type ecosystems of central Chile. In: Davies GW \& DM Richardson (eds) Mediterraneantype ecosystems: the function of biodiversity: 185228. Springer-Verlag, Berlin, Germany.

GÓMEZ M (2003) Contenido de carbohidratos en el lignotuber de Cryptocarya alba (Mol.) Looser y respuestas morfológicas de los rebrotes producidos a partir de él, durante la regeneración post-fuego, en el matorral de Chile central. Tesis de Magíster, Facultad de Ciencias, Universidad de Chile, Santiago, Chile. vii+60 pp.

HANES TL (1971) Succession after fire in the chaparral of southern California. Ecological Monographs 41: 27-52.

KEELEY SC \& AW JOHNSON (1977) A comparison of the pattern of herb and shrub growth in comparable sites in Chile and California. American Midland Naturalist 97: 120-132.

KEELEY JE (1981) Reproductive cycles and fire regimes. In: Mooney HA, TM Bonnicksen, NL Christensen, JE Lotan \& WA Reiners (eds) Proceedings of the conference on fire regimes and ecosystem properties: 231-277. United States Department of Agriculture, Forest Service General Technical Report WO-26, Washington, District of Columbia, USA.

KEELEY JE (1982) Distribution of lightning and mancaused wildfires in California. In: Conrad CE, WC Oechel (eds) Proceedings of the symposium on dynamics and management of Mediterranean-type ecosystems: 431-437. United States Department of Agriculture, Forest Service, Pacific Southwest Forest and Range Experiment Station, General Technical Report PSW-58, USA.

KEELEY JE (1986) Resilience of Mediterranean shrub communities to fire. In: Dell B, AJM Hopkins \& BB Lamont (eds) Resilience in Mediterranean-type ecosystems: 95-112. Dr. W Junk, Dordrect, The Netherlands.

KEELEY JE (1993) Smoke-induced flowering in the firelily Cyrtanthus ventricosus. South African Journal of Botany 59: 638.

KEELEY JE (1994) Seed germination patterns in fireprone Mediterranean-climate regions. In: Arroyo MTK, PH Zedler \& MD Fox (eds) Ecology and biogeography of Mediterranean ecosystems in Chile, California and Australia: 239-273. SpringerVerlag, New York, New York, USA.

KEELEY JE \& S KEELEY (1986) Chaparral and wildfires. Fremontia (United States) 14: 18-21.

KEELEY JE \& CJ FOTHERINGHAM (1997) Trace gas emissions in smoke-induced seed germination. Science 276: 1248-1250. 
KEELEY JE, PH ZEDLER, CA ZAMMIT \& TJ STOHLGREN (1989) Fire and demography. In: Keeley SC (ed) The California chaparral: paradigms reexamined: 151-153. Science Series: 34. Natural History Museum of Los Angeles County, Los Angeles, California, USA.

LE MAITRE DC \& PJ BROWN (1992) Life cycles and fire stimulated flowering in geophytes. In: van Wilgen BW, DM Richardson, FJ Kruger \& HJ van Hensbergen (eds) Fire in South African mountain fynbos: 145-160.Springer-Verlag, Berlin, Germany.

LEPART J \& M DEBUSCHE (1992) Human impact on landscape patterning: Mediterranean examples. In: Hansen AJ \& F di Castri (eds) Landscape boundaries consequences for biotic diversity and ecological flows: 76-106. Springer-Verlag, New York, New York, USA.

MINNICH RA (1989) Chaparral fire history in San Diego county and adjacent northern Baja California: an evaluation of natural fire regimes and the effects of suppression management. In: Keeley SC (ed) The California chaparral: paradigms reexamined: 37-47. Science Series: 34. Natural History Museum of Los Angeles County, Los Angeles, California, USA.

MONTENEGRO G, G ÁVILA \& P SCHATTE (1983) Presence and development of lignotubers in shrubs of the Chilean matorral. Canadian Journal of Botany 61: 1804-1808.

MONTENEGRO G, F DÍAZ, M GÓMEZ \& $R$ GINOCCHIO (2002) Regeneration potential of Chilean matorral alter FIRE: an updated view. In: Veblen T, W Baker, G Montenegro \& T Swetnam (eds) Fire and climate change in temperate ecosystems of the western Americas: 375-403. Springer-Verlag, New York, New York, USA

MOONEY HA (ed) (1977) Convergent evolution of Chile and California Mediterranean climate ecosystems. Dowden, Hutchinson \& Ross, Stroudsburg, Pennsylvania, USA.

MOONEY HA, EL DUNN, F SHROPSHIRE \& L SONG (1970) Vegetation comparisons between the Mediterranean climate areas of California and Chile. Flora 159: 480-496.
MOONEY HA, SP HAMBURG, \& JA DRAKE (1986) The invasions of plants and animals into California. In: Mooney HA \& JA Drake (eds) Ecology of biological invasions of North America and Hawaii: 250-272. Springer-Verlag, New York, New York, USA.

MOONEY HA \& DJ PARSONS (1973) Structure and function of the California chaparral and example from San Dimas. In: di Castri F\& HA Mooney (eds) Mediterranean ecosystems: origin and structure: 83112. Springer-Verlag, New York, New York, USA.

MUÑOZ MR \& ER FUENTES (1989) Does fire induce shrub germination in the Chilean matorral? Oikos 56: $177-181$.

PALMER T (1993) California's threatened environment. Island Press, Washington, District of Columbia, USA.

PARSONS DJ (1976) Vegetation structure in the Mediterranean climate scrub communities of California and Chile. Journal of Ecology 64: 435-447.

PARSONS DJ \& AR MOLDENKE (1975) Convergence in vegetation structure along analogous climate gradients in California and Chile. Ecology 56: 950-957.

RUNDEL PW (1981). Fire as an ecological factor. In: Lange OL, PS Nobel, CB Osmond \& H Ziegler (eds) Physiological plant ecology I: 501-538. Springer-Verlag, New York, New York, USA.

RUNDEL PW (1996) Monocotyledonous geophytes in the California flora. Madroño (United States) 43: 355-368.

RUNDEL PW, GA BABER, DJ PARSONS \& TJ STOHLGREN (1987) Post-fire demography of resprouting and seedling establishment by Adenostoma fasciculatum in the California chaparral. In: Tenhunen JD, FM Cantrino, OL Lange \& WC Oechel (eds) Plant response to stress. Functional analysis in Mediterranean ecosystems: 575-596. Springer-Verlag, Berlin, Germany.

STONE EC (1951) The stimulative effect of fire on the flowering of the golden brodiaea (Brodeaiea ixiodes Wats. var. lugens Jeps.). Ecology 32: 534-537.

WELLS PV (1969) The relation between mode of reproduction and extent of speciation in woody genera of the California chaparral. Evolution 23: 264-267.

ZUNINO S \& G RIVEROS (1990) Cartografía de los incendios forestales en la quinta región. Anales Museo de Historia Natural, Valparaíso 21: 89-94. 